\title{
Enhancement of Artificial Infiltration Capacity in Low Permeability Soils for Gaza Coastal Aquifer
}

\author{
Said M. Ghabayen ${ }^{1}$, Abdelmajid Nassar ${ }^{1}$, Safaa El Dirawi ${ }^{1}$, Hind Rashwan ${ }^{1}$ \& Haneen Sarsour ${ }^{1}$ \\ ${ }^{1}$ Environmental Engineering Department, Islamic University of Gaza, Palestine \\ Correspondence: Said M. Ghabayen, Environmental Engineering Department, Islamic University of Gaza, Gaza, \\ Palestine. Tel: 972-599-762-562. E-mail: sghabayen@iugaza.edu.ps
}

Received: October 29, 2013 Accepted: November 11, 2013 Online Published: November 27, 2013

doi:10.5539/enrr.v3n4p155 URL: http://dx.doi.org/10.5539/enrr.v3n4p155

\begin{abstract}
Water is a key component in determining the quality of our lives. Today, people are concerned about the quality of the water they drink. Groundwater aquifer is considered the main and the only water supply source for all kinds of human usage in the Gaza Strip which is severely deteriorated in-terms of quality and quantity in the past two decades. In the past years, several researches have been conducted on the enhancement of the role of storm water infiltration system aimed mainly at improving the quality and the availability of water. This paper investigates methods to enhance the storm water infiltration capacity of Sheikh Radwan Reservoir by using soil column pilot experiment of specific sand media and simulating the real situation using the MODFLOW groundwater flow model. The sample of storm water was collected from the reservoir in the wet season, and was allowed to infiltrate through the soil column of $170 \mathrm{~cm}$ depth in the soil experiment. The results of soil experiment showed that the quality of infiltrated water (BOD, COD, Suspended Solid, Ammonia) was found to conform to Palestinian standard for aquifer infiltration with $90 \%$ percent removal of contaminants, which indicate the effectiveness of the used soil media. The simulation of MODFLOW model was done considering different number and distribution of infiltration wells. The results showed an increase of water quantity in groundwater aquifer with maximum water level mound of $6 \mathrm{~m}$ beneath the reservoir after 3 months of flooding, and started to decrease gradually to reach $-2 \mathrm{~m}$ to $-3 \mathrm{~m}$ in the dry season which reflect the normal situation. The results of the study showed that 33 infiltration wells are needed to evacuate the collected storm water at the reservoir within 10 days which satisfy the function of the reservoir as flood relief and infiltration. Also it is recommended by the study to increase the sand filter depth to $2 \mathrm{~m}$, in order to improve the removal percentage of contaminants to reach $100 \%$.
\end{abstract}

Keywords: artificial recharge, groundwater aquifer, Gaza, soil column experiment, Modflow, storm water quality

\section{Introduction}

Groundwater aquifer is the sole sources of freshwater in the Gaza Strip. Unfortunately, it suffers from a yearly deficit of 30-40 Mm3 due to over-abstraction of water and low rainfall (200-400 mm/year) (Rabah et al., 2011; CMWU, 2008). The deficit is increasing with time due to the rapid population growth (Nassar et al., 2009) and the decreasing rainfall infiltration rates resulting from the rapid urbanization activities (Khalaf et al., 2006).

The Sheikh Radwan Reservoir is one of the largest storm water collection reservoir in the Gaza Strip. The collected water is usually discharged directly to the sea due to impermeable soil profile beneath the reservoir bottom. The artificial storm water recharge is found to be one of the feasible options to compensate for the Gaza aquifer deficit (Metcalf \& Eddy, 2003).

Artificial recharge used for storing excess surface water underground in order to increase water supply to meet excess demand, artificial recharge may be used to store treated sewage effluent and excess storm water runoff for later use (Herman, 1996).

Soil aquifer treatment (SAT) is a new technology developed for treating water of water deterioration. Soil aquifer treatment is practiced in several countries and can improve the quality of water in the stage of infiltration, for many reasons including the adsorption of microorganisms and heavy metal to the soil particles and the decomposition of some chemicals such as Nitrogen and Phosphorus. Biological activity is enhanced with 
increasing depth of the filter. We can expect the highest removal efficiency at higher sand depths (Ellis, 1984; Arye et al., 2011). Higher removal efficiencies acquired at lower removal rates, higher sand depths, and smaller sand size, respectively (Khan, 1995; Essatudtiesndoh et al., 2011; Essandoh et al., 2013).

In general, the performance of the filter material in SAT systems is evaluated with water quality parameters including the concentration of suspended solids, heavy metals, organic matters, and total coliforms and fecal coliforms (EPA, 1999; Clark et al., 2007; Azaroual, 2013). Total Suspended Solids (TSS) are solids in water can be captured by a filter. It contains a large variety of materials, such that silt, decaying plant and animal matter, industrial wastes, and sewage. Several problems can be caused by high levels of TSS in urban runoff that may exceed EPA water Quality criteria through and after storm events (EPA, 1999; Maeng et al., 2010).

Runoff water can also contain high levels of heavy metals concentrations such as chromium, copper, and zinc. The previous SAT experiments showed reduction total metals concentrations and TSS up to 80\% (Herman, 1996) In a research conducted through the National Urban Runoff Program, 17 sites and for 156 storm events were evaluated and the results showed high levels of fecal coliform and total coliform bacteria in urban runoff that exceed EPA water Quality criteria through and after storm events (EPA, 1999). In a similar experiment, considering multiple soil columns and silt loam soil, the removal percentage ranged from $78 \%$ to $99 \%$ for total coliforms and from 79\% to 99\% for fecal coli forms (Lian et al., 2013; Khan, 1995).

Modflow is a three-dimensional finite-difference groundwater flow model. It is the most widely-used groundwater model in the world to simulate the aquifer systems for water supply, containment treatment, external flow stresses like wells, areal recharge such as artificial infiltration systems (Harbaugh et al., 2000; Dong et al., 2012; Gao, 2011).

\section{Study Area}

\subsection{Location}

The Gaza Strip (GS) is located on the southeastern coast of the Mediterranean Sea as shown in Figure 1, on the edge of the Sinai Desert between longitudes $34^{\circ} 2^{\prime \prime}$ and $34^{\circ} 25^{\prime \prime}$ east, and latitudes $31^{\circ} 16^{\prime \prime}$ and $31^{\circ} 45^{\prime \prime}$ north. It has an area of about $365 \mathrm{~km}^{2}$ and its longest width is about $45 \mathrm{~m}$ (MOPIC, 1998).

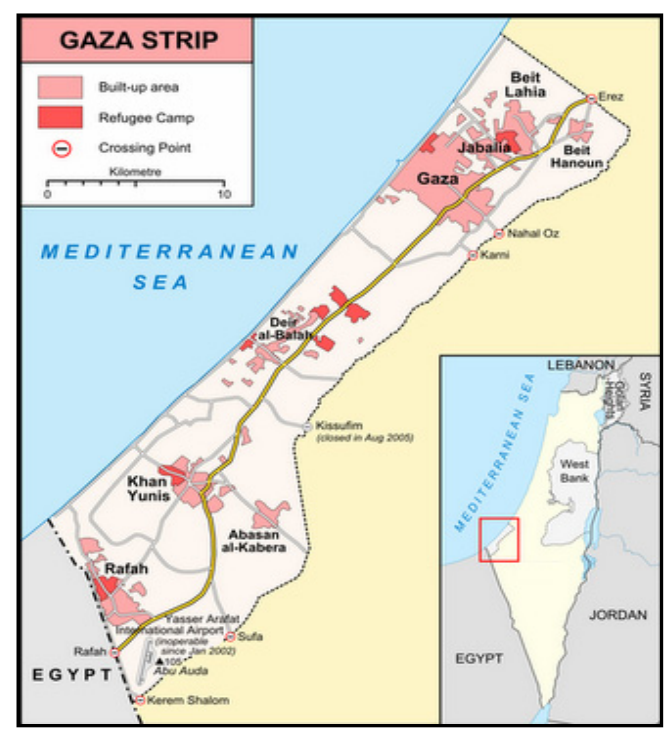

Figure 1. National Geographic location of GS (Courtesy of Wikipedia)

\subsection{Climate}

GS climate is typical Eastern Mediterranean with hot dry summers and mild winters. The temperature gradually changes throughout the year, reaches its maximum in August (summer) and its minimum in January (winter), the average monthly maximum temperature range from about $17.6^{\circ} \mathrm{C}$ in January to $29.4{ }^{\circ} \mathrm{C}$ in August while the average monthly minimum temperature for January is about $9.6^{\circ} \mathrm{C}$ and $22.7^{\circ} \mathrm{C}$ for August (Qahman, 2009). The GS is located in the transitional zone between the arid desert climate of the Sinai Peninsula in Egypt and the 
temperate and semi-humid Mediterranean climate along the coast. This fact could explain the sharp decrease in rainfall quantities of more than $200 \mathrm{~mm}$ /year between Beit-Lahia in the north and Rafah in the South of GS (Sami, 2007). The average long term annual rainfall is $350 \mathrm{~mm}$ occurs between October and March. The long-term average annual open surface evaporation is $1300 \mathrm{~mm}$ with its maximum in summer season (June August).

\subsection{Gaza Coastal Aquifer}

The entire GS lies within the Coastal groundwater basin over the Coastal Aquifer. The Coastal Basin covers an area of 2,000 square kilometers as shown in Figure 2, and is located in the Coastal Plain physiographic province. The Coastal Aquifer is comprised of water-bearing sand, sandstone, gravel, and conglomerate that typically overlies relatively impervious clay, marl, limestone, and chalk (EXACT, 1998).

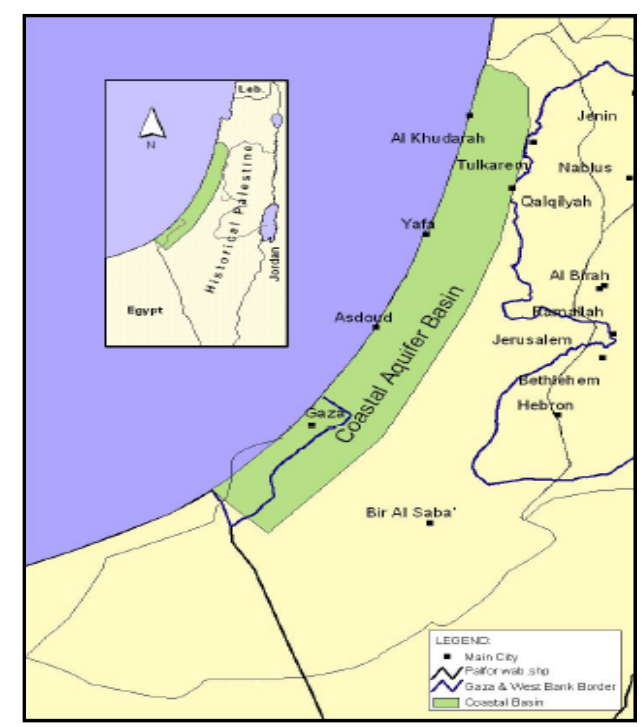

Figure 2. Location of Gaza Coastal Aquifer in Palestine (MEDA, 2007)

This aquifer extends over a distance of $120 \mathrm{~km}$ starting from south the of mount of Carmel (Haifa) and ending over in the Gaza Strip, it has a width of $7-20 \mathrm{~km}$ and it disappears near the foot hills of the mountains of the West Bank (Al-Najar, 2011). There are an estimated 4000 wells within the Gaza Strip. Almost all of these are privately owned and used for agricultural purposes. Approximately 100 wells are owned and operated by individual municipalities and are used for domestic supply (PWA, 2005).

\subsection{Shiekh Radwan Reservoir}

The Shiekh Radwan Reservoir is located northwest of Gaza City (Figure 3). It has a surface area of $88000 \mathrm{~m}^{2}$. The site is almost flat and the bottom of the reservoir is elevated at about $+16 \mathrm{~m}$ MSL. The reservoir receives about $2.5 \times 106 \mathrm{~m}^{3}$ annually from a catchment area of about $25 \mathrm{~km}^{2}$ (PWA, 2011). The sides of the reservoir are supported by gabion walls. The capacity on the reservoir is $560,000 \mathrm{~m}^{3}$. Table 1 and Figure 4 summarizes the soil properties beneath the bottom surface of the reservoir. It starts with $0-1 \mathrm{~m}$ brown silty sand layer, underlain by 1-6 m brown soft clay then $6-11.5 \mathrm{~m}$ clayey sand layer. Underneath all that, there is a calcareous sand layer that continues up to the bottom of the unconfined aquifer. 


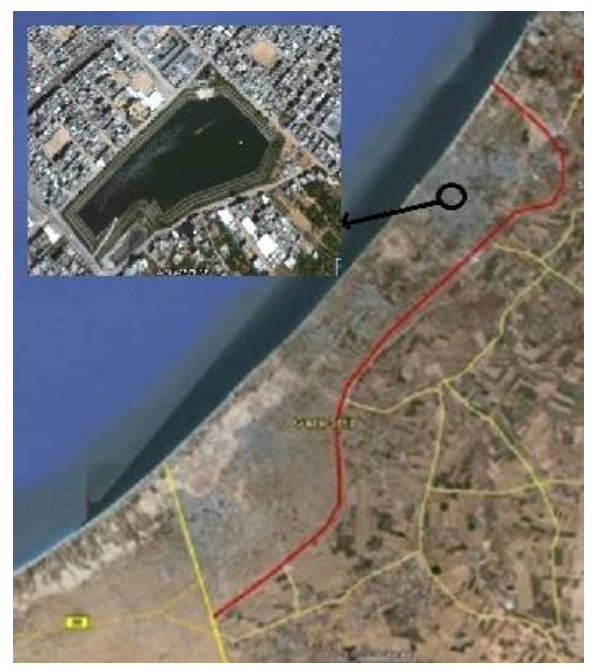

Figure 3. Location Map of Shiekh Radwan Reservoir

Table 1. The soil stratification below the bottom of the reservoir (PWA, 2011)

\begin{tabular}{cccc}
\hline Layer & Depth from the reservoir surface $(\mathrm{m})$ & Description & Permeability $[\mathrm{m} / \mathrm{d}]$ \\
\hline 1 & $0-1$ & brown silty sand & $0.2-1$ \\
2 & $1-6$ & brown soft clay & 0.003 \\
3 & $6-11.5$ & clayey sand & $0.002-0.007$ \\
4 & $11.5->14$ & calcareous sand & $4-6$ \\
\hline
\end{tabular}

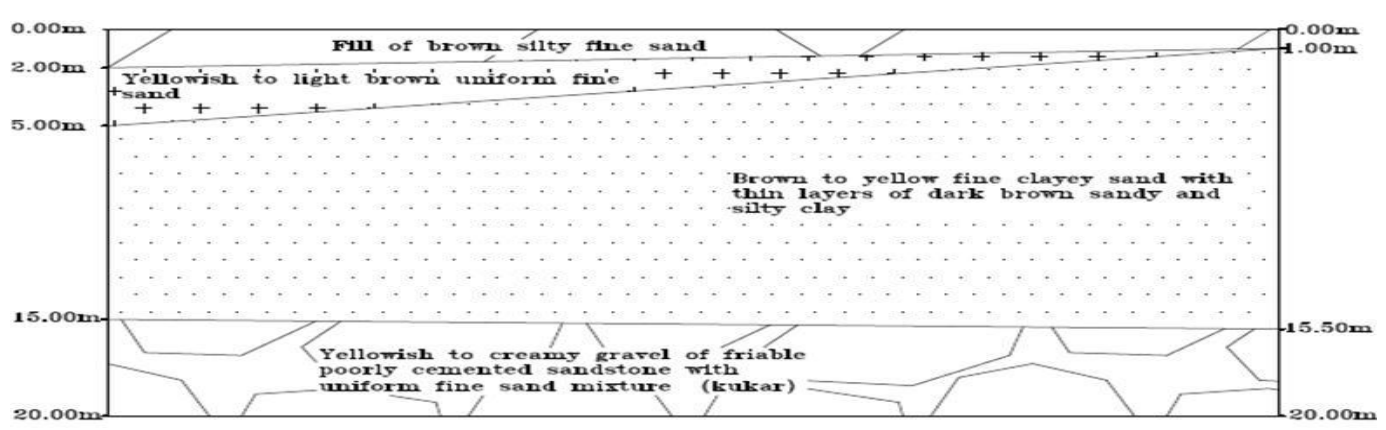

Figure 4. Geotechnical Cross Section in Sheikh Radwan Reservoir

\section{Objectives}

The goal of this research was to study ways for the enhancement of infiltration capacity of the bottom soil layers of the Sheikh Radwan storm water reservoir and investigate the effectiveness of the enhancement method in improving the quality of the infiltrated storm water.

\section{Materials and Methods}

\subsection{Laboratory Experiment}

In order to strengthen the possibility of a filter layer design above the base of the reservoir and how it can treat the storm water with better quality, a soil-column experiment reflecting the proposed filter design have been conducted (Figure 5). The pilot filter consisted of a reinforced 8-inch diameter and $2 \mathrm{~m}$ long plastic cylinder. The cylinder contained two types of gravel media. A $15 \mathrm{~cm}$ gravel layers were placed at the bottom and at half height to allow easy and distributed drainage of the water from two locations. Two layers, $80 \mathrm{~cm}$ each, of poorly graded sand media were placed at the top of gravel media. The infiltrated water was tested in the middle and at the 
bottom to check the effectiveness of the designed filter.

The storm water samples were collected from the inlet of the Sheikh Radwan reservoir then it was allowed to infiltrate through the designed sand filter. The treated storm water samples were then tested for quality parameter; Physical, Chemical and Biological.

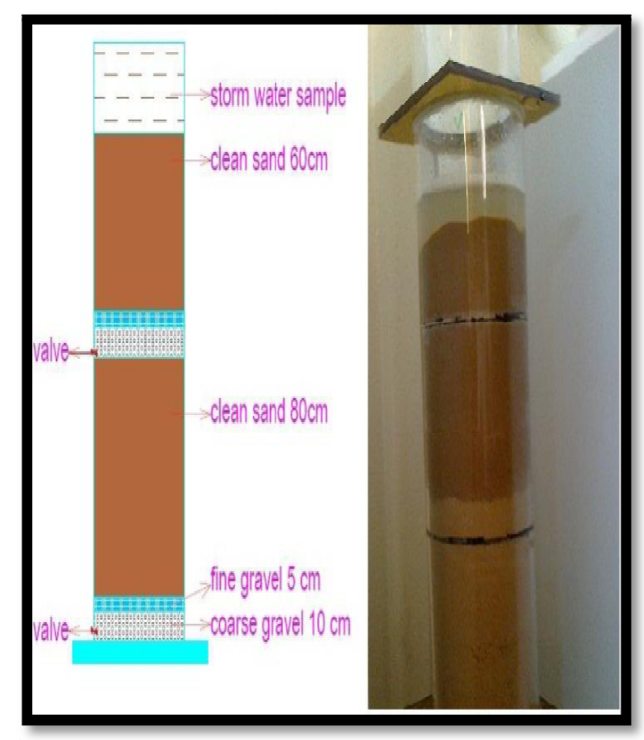

Figure 5. Soil Column Experiment Diagram

\subsection{Groundwater Model}

Visual MODFlOW 4.21 software, based on Harbaugh and McDonald (2000), was utilized to build a groundwater model for the study area. The purpose of the groundwater modeling was to get a more comprehensive view of the mounding of water table and the effect of recharge of storm water into aquifer. The formation of the model is critical to the development of a more quantitative representation of the subsurface hydrology and the dominating hydrogeological and hydrological conditions (Lachaal et al., 2013).

The Model Domain enclosed an area of $3 \times 3 \mathrm{~km}$ for the reservoir as well as the surrounding area. A specific head boundaries were assigned for the eastern and western boundary based on the data from a contour map of groundwater level for the year 2007 (Qahman, 2009). The northern and the southern boundaries were considered as stable no-flow boundaries.

The model domain was divided into a $100 \times 100$ grid with cell size ranging from $50 \times 50 \mathrm{~m}$ in the reservoir area to $200 \times 200 \mathrm{~m}$ for the surrounding area. The model consisted of three layers as shown in Figure 6 . The first layer is the top layer consisting of a sand dune with a thickness of about $2 \mathrm{~m}$. The second layer is the clay layer with thickness of about $11.5 \mathrm{~m}$ and the last layer is the calcareous sand with a thickness of about $180 \mathrm{~m}$. 


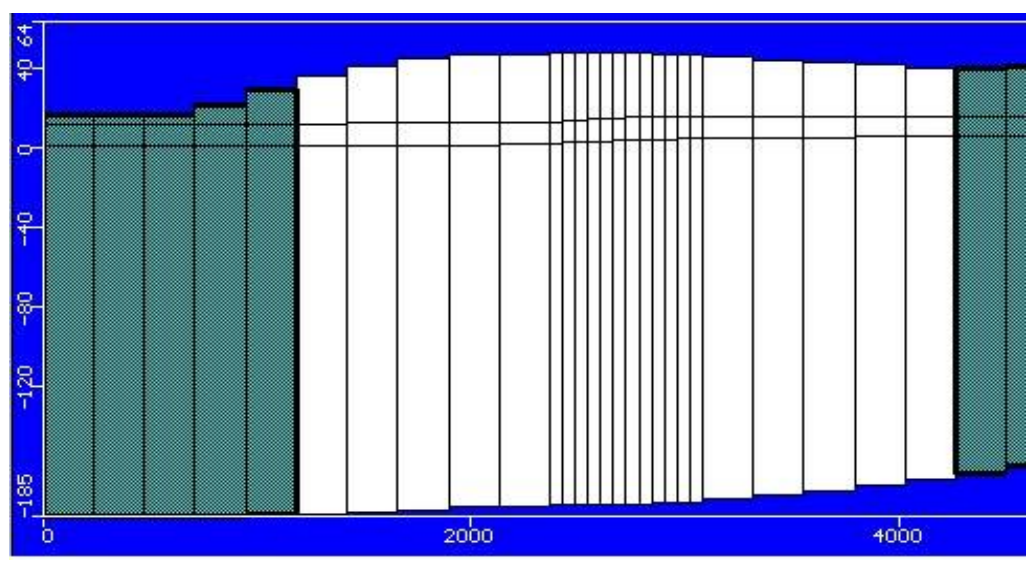

Figure 6. Modeled Aquifer Layers

The default hydraulic parameters of the model are based on Coastal Aquifer Management Plan model report (Metcalf \& Eddy, 2000). The vertical conductivity was set to $10 \%$ of the horizontal hydraulic conductivity and the horizontal hydraulic conductivity of the saturated zone for the soil types investigated was set at $30 \mathrm{~m} / \mathrm{d}$ in sand with fine gravel and $0.3 \mathrm{~m} / \mathrm{d}$ for clay (Metcalf \& Eddy, 2000). The estimated input data for the model are summarized in the Table 2.

Table 2. Hydraulic Parameters of Groundwater Model

\begin{tabular}{llll}
\hline Parameter & Dune sand & Clay & Kurkar \\
\hline Hydraulic conductivity (Kx ,Ky), m/d & 18 & 0.3 & 30 \\
Hydraulic conductivity (Kz), m/d & 1.8 & 0.3 & 3 \\
Specific storage (Ss), $\mathrm{m}^{-1}$ & $1 . \mathrm{E}-05$ & $1 . \mathrm{E}-05$ & $1 . \mathrm{E}-05$ \\
Specific yield (Sy) & 0.24 & 0.1 & 0.24 \\
Effective porosity & 0.25 & 0.4 & 0.25 \\
Total porosity & 0.3 & 0.5 & 0.3 \\
\hline
\end{tabular}

Sinks in the model are mainly represented by the existing abstraction wells. Sources are mainly the recharge from the rainfall and the artificial injection wells. Average rainfall depth in Gaza city station is $460 \mathrm{~mm} / \mathrm{year}$ (PWA, 2007).

As most of the surrounding is agricultural areas, the average natural infiltration rate into aquifer from the study area is estimated $300 \mathrm{~mm} /$ year (Qahman, 2009). In the model domain. There are about 14 municipal wells with approximate abstraction $2400 \mathrm{~m}^{3} / \mathrm{d}$ and about 50 agriculture wells with approximate abstraction $85 \mathrm{~m}^{3} / \mathrm{d}$ (PWA, 2007). Four wells were selected as head observation wells for the model local calibration. The observation wells data were taken from the Palestinian Water Authority (PWA, 2007).

Artificial recharge/infiltration wells were used in model to recharge collected storm water into the aquifer. Based on several trials for the number of wells and for their distribution, the number of wells in the infiltration basin is 33 wells of $25 \mathrm{~m}$ depth. Figure 7 shows the distribution of the proposed infiltration at reservoir base. 


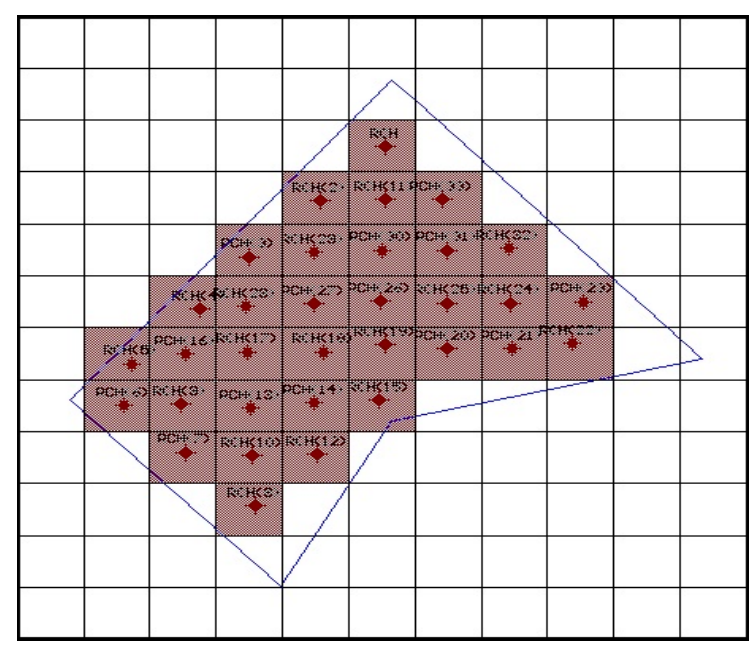

Figure 7. Distribution of the Proposed Infiltration Wells

\section{Results and Discussion}

\subsection{Results and Discussion of Laboratory Experiment}

The tests for the water quality parameters were performed at Birzeit University laboratory. Figure 8 below shows the results of laboratory analysis for $\mathrm{NO}_{3}, \mathrm{TSS}, \mathrm{NH} 4, \mathrm{COD}$, and BOD at the top, at the middle point, and at the bottom of the filter. The TSS concentration was reduced from $116 \mathrm{ppm}$ to $15 \mathrm{ppm}$ which made it satisfy the Palestinian standards for infiltration to the groundwater aquifer $(20 \mathrm{ppm})$. In practice of artificial recharge, clogging of the filter layer usually occurs at the very top and can be treated by regular plowing and scrapping of the top layer (Bouri et al., 2010).

The laboratory analysis results, Figure $8 \mathrm{~d}$, shows an increase in the nitrate concentration with depth from 2.8 to $7.5 \mathrm{mg} / 1 \mathrm{NO}_{3}-\mathrm{N}$ and a decrease in ammonia concentration with depth from 5.4 to $0.39 \mathrm{NH}_{4}-\mathrm{N}$. This may reflect the process of oxidation of ammonia and other nitrogen compounds to nitrates on the surface and in the upper part of the filter. The resulted nitrate concentration is well below the Palestinian standards for infiltration to the groundwater aquifer $\left(10 \mathrm{mg} / \mathrm{l} \mathrm{NO} \mathrm{N}_{3}-\mathrm{N}\right)$.

COD have decreased from $170 \mathrm{mg} / \mathrm{l}$ to reach $75 \mathrm{mg} / \mathrm{l}$ and BOD has decreased from $40 \mathrm{mg} / \mathrm{l}$ to $10 \mathrm{mg} / \mathrm{l}$ which reflect the effectiveness of the selected sand filter. The starting COD concentration was high because the samples were collected after the first storm event which usually collect accumulated chemicals from the roads. The situation is expected to improve with the consecutive storms. 


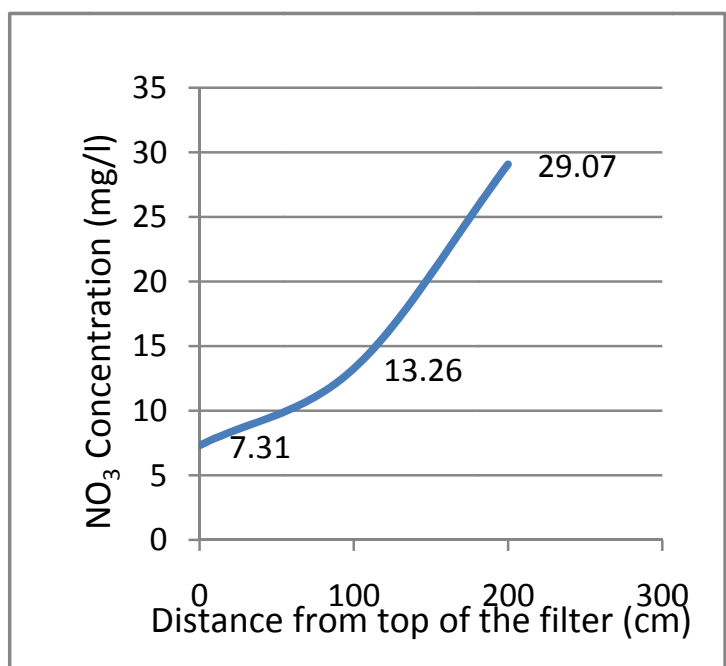

Figure 8a. Nitrate Analysis Results

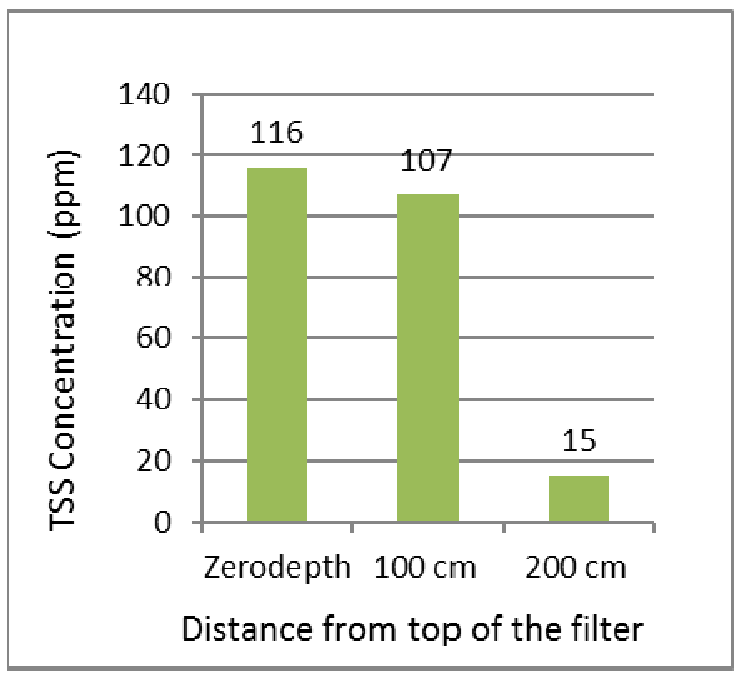

Figure 8b. Suspended Solids Analysis Results
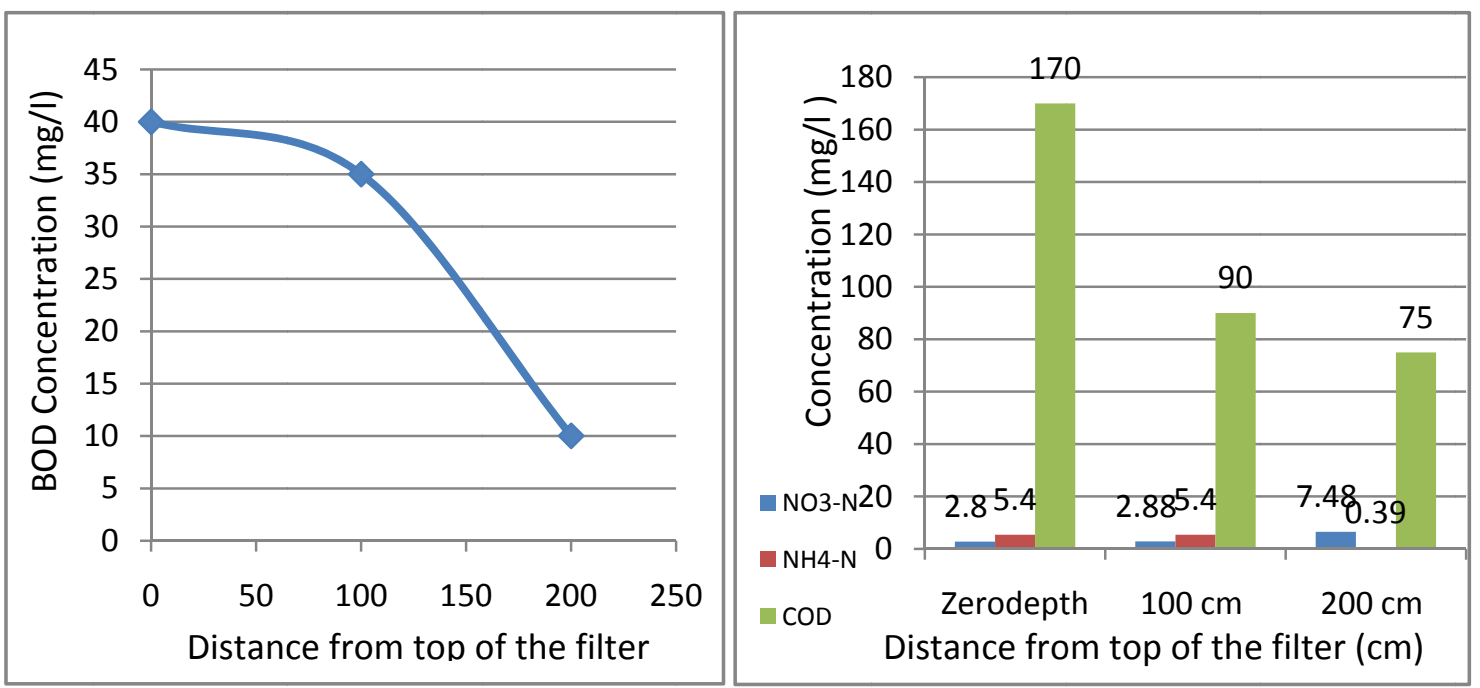

Figure 8c. BOD Analysis Results

Figure 8d. Nitrates, Ammonia, and COD Analysis Results

Figure 8. Physical and Chemical Parameters Results for the Soil Experiment

The existence of fecal coliform (FC) bacteria and high BOD in the collected storm water is an indication of mixing of urban wastewater with the storm water. This case is occurring in the study area due to due to uncontrolled sewage drainage to the streets and/or the flooding of wastewater manholes during the heavy storms. (Table 3) below shows the laboratory analysis average results for the fecal coliform in the collected storm water before and after the sand filter. At the top of the sand filter the FC bacteria was too numerous to count (TNT). The number was reduced to zero in the middle of the filter as well as at the bottom of the filter. This indicates a very efficient treatment of FC through the sand filter.

Table 3. Fecal Coliform Analysis Results

\begin{tabular}{cccc}
\hline Depth of sand filter $(\mathrm{cm})$ & Zero & $100 \mathrm{~cm}$ & $200 \mathrm{~cm}$ \\
\hline Concentration $(\mathrm{CFU} / 100 \mathrm{ml})$ & TNT & 1 & 0 \\
\hline
\end{tabular}

The results of the soil experiment in terms of physical, chemical and biological parameters can be summarized 
with points below:

With respect to the physical process of the filter, TSS was found to be high before treatment due to a heavy suspended matter that was loaded during street runoff. After passing through the soil filter, the average removal percentage of the TSS from all samples was $87 \%$.

Considering the chemical processes, a decrease in ammonia concentration associated with an increase in nitrate concentration indicates the effectiveness of the surface infiltration systems in oxidizing ammonia and other unstable nitrogen compounds to more stable forms. The average percentage removal of ammonia has reached to about $92 \%$ from its initial value. The remaining ammonia is expected to be further treated either by nitrification or de-nitrification through the deeper soil layers. Furthermore, the initial value of COD before infiltration was high due to existence of organic pollutant which should not be the case for pure storm water. However, the percentage treatment of COD was about $60 \%$ through the $160 \mathrm{~cm}$ filter.

With regard to the biological processes, on average, there was $75 \%$ removal of the BOD and total removal of FC bacteria through the filter. Hence, the selected filter material was effective in reducing the hazards of contamination with pathogens and accidental urban wastewater.

\subsection{Results and Discussion of Groundwater Model}

Figure 9 shows the results of the groundwater level simulations beneath the reservoir area before the start of infiltration, after the end of the wet season, and after the one year cycle, just before the start of another wet season. The water table elevation has been in the range of 1.5 to 3.0 meters below the MSL just before any infiltration activities. Considering a 2 meter top sand filter and 33 infiltration wells (Figure 7), the collected water from each storm will be able to percolate down in the unsaturated zone and ultimately to the groundwater aquifer in about 10 days from the start of each storm. After that the collected water will be stored in the soil below the reservoir bottom and should not affect the storage capacity of the reservoir to accommodate any other storm.

With consecutive storms and after the end of the wet season (October to March), the maximum groundwater table elevation would be 6 meters above MSL just below the center of the reservoir (Figure 9b). This water table elevation is still 10 meters below the bottom elevation of the reservoir which shows that the proposed system is capable of absorbing all the collected water without creating groundwater mounding problems below the infiltration zone.

Figure 9c shows that the original groundwater table elevation has been restored to almost its original value at the end of one hydrologic year. This indicates the capacity of the aquifer system to accommodate the infiltrated water effectively.

\section{Conclusions}

This research investigated the possibility to utilize one of the largest storm water collection reservoirs in Gaza Strip for recharging the groundwater aquifer. In this regard, two major concerns were resolved:

1) With regard to the low permeability of the soil beneath the bottom of the reservoir, the issue was resolved by enhancing the infiltration rate by recharge wells through the impermeable layers. The effectiveness of the design was checked by MODFLOW simulation of the flow. The results of the simulation showed that groundwater mound below the reservoir will be dispersed and will not rise to the bottom surface of the reservoir.

2) With regard to the risk of contamination of the groundwater aquifer from the runoff water, the issue was clarified by the proposed 2 meter sand filter layer that overlay the recharge wells. It was shown through the laboratory experiment that the sand filter was effective in treatment of contaminated storm water to high levels that satisfy the local Palestinian standards for aquifer recharge.

For semi-arid areas, like Gaza Strip, storm water infiltration can contribute significantly to water availability and water quality improvement if utilized in a careful manner. The outcome of this research contribute to clarifying some of the issues concerning the design of optimal infiltration system that can enhance the available quantity and lowering the risk of pollution of groundwater aquifer. 


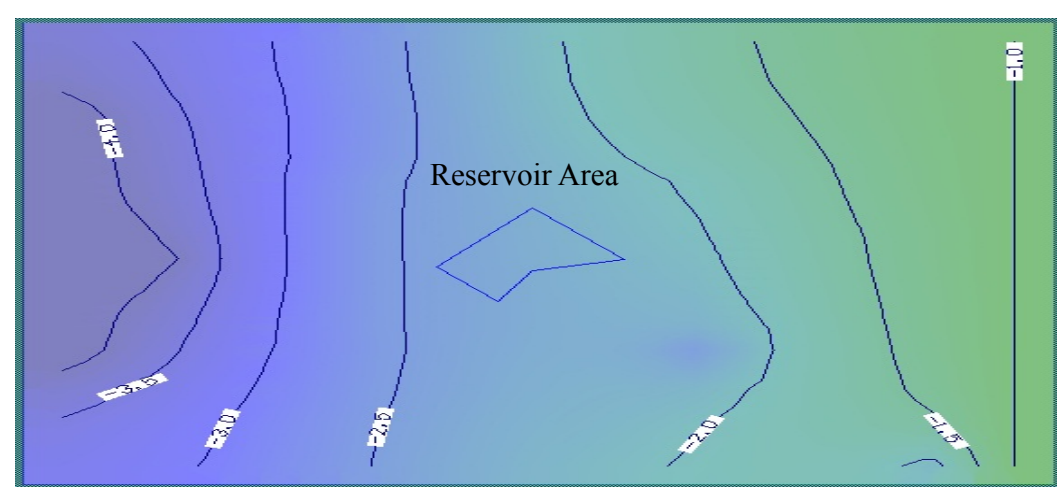

Figure 9a. Initial groundwater level

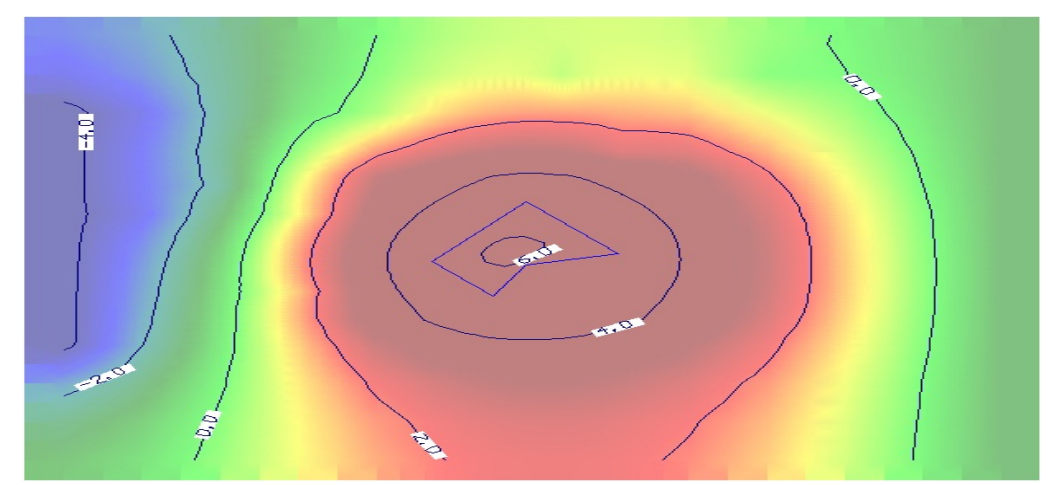

Figure 9b. After the wet season

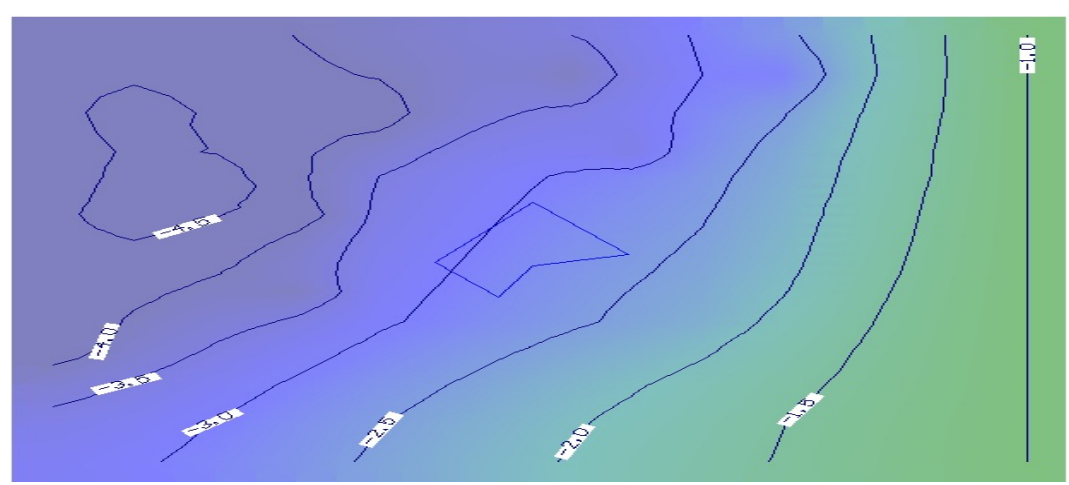

Figure 9c. After one year cycle

Groundwater Elevation m MSL:

$$
\begin{aligned}
& 6 m-4 m \\
& 4 m-2 m \\
& 2 m-0 m \\
& 0 m-2 m \\
& -2 m-4 m
\end{aligned}
$$

Figure 9. Simulated Groundwater Levels 


\section{References}

Arye, G., Tarchitzky, J. \& Chen, Y. (2011). Treated Wastewater Effects on Water Repellency and Soil Hydraulic Properties of Soil Aquifer Treatment Infiltration Basins. Journal of Hydrology, 397(12), 136-145. http://dx.doi.org/10.1016/j.jhydrol.2010.11.046

Azaroual, M., Pettenati, M., Ollivier, P., Besnard, K., Casanova, J., \& Rampnoux, N. (2013). Reactive Transfer of Pollutants through the Unsaturated Soil Zone during an Artificial Aquifer Recharge Process. Earth and Planetary Science, 7, 40-43. http://dx.doi.org/10.1016/j.proeps.2013.03.169.

Bouri, S., \& Ben D. H. (2010). A Thirty-year Artificial Recharge Experiment in a Coastal Auifer in an Arid Zone: The Teboulba Aquifer System (Tunisian Sahel). Comptes Rendus Geoscience, 342(1), 60-74. http://dx.doi.org/10.1016/j.crte.2009.10.008

Bruijn, H., \& Clark S. E. (2003). Research and Development of Effective Suspended Solids Removal from Storm Water Runoff in Collection Systems Using In-Line Lamella Plate Separators. Terrehill Concrete $\begin{array}{lllll}\text { Products. } & \text { Retrieved } \quad \text { May } & \text { 15, } & \text { from }\end{array}$ http://www.terrehill.com/documents/09_19_03_villanovapaperterrekleen_001.pdf

Clark, S. E., Pratap, M., Pitt, R., Khambhammettu, U., Roenning C., Treese C. D., \& Siu C. Y. S. (2007). Runoff Polishing by Natural Media Filtration: Up Flow vs. Down Flow. Pennsylvania Storm water Management Symposium (October, 2007, pp. 17-18). Villanova Urban Stormwater Partnership, Villanova, PA.

Coastal Municipalities Water Utility (CMWU). (2008). Water and Wastewater Quality in Gaza Strip for Years 2007 and 2008. CMWU Annual Report.

Coastal Municipalities Water Utility (CMWU). (2009). Gaza Water Status and Strategic Future Plan. Gaza, Palestine.

Dong, Y., Li, G., \& Xu, H. (2012). An Areal Recharge and Discharge Simulating Method for MODFLOW. Computers \& Geosciences, 42, 203-205. http://dx.doi.org/10.1016/j.cageo.2011.10.005

Ellis, V. (1984). Slow Sand Filtration. Critical Reviews in Environmental Control, 15(4), 315-354. http://dx.doi.org/10.1080/10643388509381736.

Environmental protection Agency (EPA). (1999). Preliminary Data Summary of Urban Storm Water Best Management Practices. EPA-821-R-99-012.

Essandoh, H. M. K., Tizaoui, C., \& Mohamed, M. H. A. (2013). Removal of Dissolved Organic Carbon and Nitrogen during Simulated Soil Aquifer Treatment. Water Research, 47(11), 3559-3572. http://dx.doi.org/10.1016/j.watres.2013.04.013

Essandoh, H. M. K., Tizaoui, C., Mohamed, M. H. A., Amy, G., \& Brdjanovic, D. (2011). Soil Aquifer Treatment of Artificial Wastewater under Saturated Conditions. Water Research, 45(14), 4211-4226. http://dx.doi.org/10.1016/j.watres.2011.05.017

Executive Action Team, EXACT. (1998). Overview of Middle East Water Resources. Middle East Water Data Banks Project. Retrieved June 21, 2013, from http://exact-me.org/overview

Gao, H. (2011). Groundwater Modeling for Flow Systems with Complex Geological and Hydrogeological Conditions. Procedia Earth and Planetary Science, 3, 23-28. http://dx.doi.org/10.1016/j.proeps.2011.09.061

Harbaugh, A., Banta, E., Hill, M., \& McDonald, M. (2000). The U.S. Geological Survey Modular Groundwater Model. User Guide to Modularization Concepts and the Groundwater Flow Process.

Herman, B. (1996). Issues in Artificial Recharge. Journal of Water Science Technology, 33(10-11), 381-390. http://dx.doi.org/10.1016/0273-1223(96)00441-6

Khalaf, A. R, Al-Najar, H., Husam, M., \& Hamad, J. (2006). Assessment of Rainwater Runoff due to the Proposed Regional Plan of Gaza Governorates. Journal of Applied Science, 6, 2693-2704. http://dx.doi.org/10.3923/jas.2006.2693.2704

Khan, A. M. (1995). Removal of Coli-phage and Bacteria through Slow Sand Filtration. M.Sc. Thesis. College of Graduate Studies, King Fahd University of Petroleum, Dhahran, Saudi Arabia.

Lachaal, F., Mlayah, A., Bédir, M., Tarhouni, J., \& Leduc, C. (2012). Implementation of a 3-D Groundwater Flow Model in a Semi-arid Region using MODFLOW and GIS Tools: The Zéramdine - Béni Hassen Miocene Aquifer System (east-central Tunisia). Computers \& Geosciences, 48, 187-198. http://dx.doi.org/10.1016/j.cageo.2012.05.007. 
Lian, J., Luo, Z., \& Jin, M. (2013). Transport and Fate of Bacteria in SAT System Recharged with Recycle Water. Journal in International Biodeterioration \& Biodegradation, 76, 98-101. http://dx.doi.org/10.1016/j.ibiod.2012.06.012

Maeng, S., Ameda, E., Sharma, S., Grützmacher, G., \& Amy, G. (2010). Organic Micropollutant Removal from Wastewater Effluent-Impacted Drinking Water Sources during Bank Filtration and Artificial Recharge. Water Research, 44(14), 4003-4014. http://dx.doi.org/10.1016/j.watres.2010.03.035

MEDA. (2007). Euro - Mediterranean Partnership project. Database on Transboundary Aquifers Version 2.1.1. Data Collection Questionnaire. Retrieved June 15, 2013, from http://www.inweb.gr/html_reports/Coastal\%20Aquifer.html. Web document Accessed on.

Metcalf, \& Eddy. (2003). The Gaza Coastal Aquifer Management Plan - Task 3, Final Report, Appendix A.

Ministry of Planning and International Cooperation. (1998). Master Plan for Sewage and Stormwater Drainage in Gaza Governorate- Final Master Plan Report. Gaza, Palestine

Najar, H. (2011). The Integration of FAO-CropWat Model and GIS Techniques for Estimating Irrigation Water Requirement and Its Application in the Gaza Strip. Natural Resources, 2, 146-154. http://dx.doi.org/10.4236/nr.2011.23020.

Nassar, A., Al-Najar, H., \& Al-Dadah, J. (2009). Socio-Economic Aspects of Wastewater Reuse in the Gaza Strip. Journal Environmental Science and Technology, 2, 170-178. http://dx.doi.org/10.3923/jest.2009.170.178

Palestinian Water Authority (PWA). (2005). Agricultural and Municipal Water Demand in Gaza Governorates for year 2005. Gaza, Palestine.

Palestinian Water Authority (PWA). (2011). Technical Assistance on Reuse of Wastewater and Storm Water Harvesting in the Gaza Strip, Austrian Project, Final Report. Gaza, Palestine.

Qahman, K., Larabi, A., Ouazar, D., Naji, A., \& Cheng, D. (2009). Optimal Extraction of Groundwater in Gaza Coastal Aquifer. Journal of Water Resource and Protection, 4, 249-259. http://dx.doi.org/10.4236/jwarp.2009.14030

Rabah, F., Ghabayen, S., \& Salha, A. (2011). Effect of GIS Interpolation Techniques on the Accuracy of the Spatial Representation of Groundwater Monitoring Data in Gaza Strip. Journal of Environmental Science and Technology, 4(6), 579-589. http://dx.doi.org/10.3923/jest.2011.579.589.

Sami, S. (2007). Nitrate Pollution and Groundwater Modeling of Wastewater Plant in Rafah Area. MSc. Thesis, Islamic University of Gaza, Gaza Strip, Palestine.

\section{Copyrights}

Copyright for this article is retained by the author(s), with first publication rights granted to the journal.

This is an open-access article distributed under the terms and conditions of the Creative Commons Attribution license (http://creativecommons.org/licenses/by/3.0/). 